\title{
UČIONICA ZA SUTRA U ZGRADI OD JUČER - KAKO ARHITEKTI I PEDAGOZI STVARAJU NOVU ŠKOLU
}

\author{
CLASSROOMS OF TOMORROW IN FACILITIES \\ FROM THE PAST - ARCHITECTS AND TEACHERS \\ DESIGNING A NEW SCHOOL
}

\author{
Sanja Lončar-Vicković ${ }^{*}$ Ivica Rumora ${ }^{* *}$
}

\begin{abstract}
Sažetak
U radu se prikazuje pregled recentnih istraživanja učioničkih prostora kroz vizuru različitih čimbenika koji definiraju izgled i organizaciju prostora za učenje, uz fokus na pojačanu prisutnost informacijsko komunikacijskih tehnologija u nastavi. Pitanja kojih se autori dotiču u radu su znanja potrebna radniku budućnosti, aktivnosti koje se provode u školi kako bi učenik ostvario ta znanja te za to potrebni prostori i njihove interakcije koje podržavaju suvremeno učenje. Članak tematizira korelaciju važnih faktora formiranja učionice 21. stoljeća, od kojih je jedan velika količina i značaj informatičke opreme, a su drugi spoznaje i dostignuća razvoja pedagoške teorije $i$ prakse. Prikazani su primjeri novih školskih prostora koji inkorporiraju opisane moderne koncepte nastave i podučavanja.
\end{abstract}

Ključne riječi: školska arhitektura, organizacija učionice, informacijsko komunikacijske tehnologije, suvremeno učenje, moderna škola

\footnotetext{
Abstract

This paper presents an overview of recent classroom space studies regarding various factors that define the layout and organization of learning spaces, focusing on the increased presence of information communication technologies in teaching. The issues that the authors are concerned with are skills needed for the future labour market, the educational activities needed to enable learners to acquire those skills and

*Građevinski i arhitektonski fakultet Osijek, Ulica Vladimira Preloga 3, 31000 Osijek

E-mail: sloncar@gfos.hr

${ }^{* *}$ Osnovna škola Svete Ane u Osijeku, Ulica Svete Ane 2, 31000 Osijek

E-mail: irumora@gmail.hr
} 
the necessary spaces (and their interactions) that support contemporary learning. The article focuses on the correlation of important factors in the formation of the $21^{\text {st }}$ century classroom, one of which is a large quantity and presence of information technology, and other findings and achievements in the development of pedagogical theory and practice. Examples of classrooms that incorporate the modern concepts of teaching in contemporary schools are illustrated.

Key words: school architecture, classroom organization, information communication technology, contemporary learning, modern school

\section{Uvod}

Svijet u kojem živimo značajno se promijenio u zadnjih pedesetak godina, a ta promjena potaknuta je prvenstveno razvojem i uporabom novih tehnologija.

Do velikih promjena došlo je i na svim razinama obrazovanja. Formalno obrazovanje postalo je fleksibilnije, s mogućnošću individualnog određivanja tempa i kontinuiteta ili diskontinuiteta školovanja te potencijalom kreiranja vlastitog programa kroz izborne predmete i projekte. Neformalno i informalno obrazovanje pojedinca postaje važan vid cjeloživotnog učenja, s naglaskom na virtualnu edukaciju. Sastavni dio svih oblika edukacije danas je i tehnologija, prije svega informacijsko komunikacijska tehnologija. U Hrvatskoj se pokreće Škola za život, reforma osnovnoškolskog i srednjoškolskog obrazovanja, koja uključuje cjelovitu reformu kurikuluma. Ciljevi reforme su razvoj temeljnih kompetencija za cjeloživotno učenje, definiranje odgojno-obrazovnih ishoda učenja koji, osim znanja uključuju i vještine, kreativnost, inovativnost, kritičko mišljenje i odgovornost, otvorene didaktičko-metodičke sustave koji omogućuju nastavnicima i učenicima slobodu u izboru sadržaja, metoda i oblika rada te jasne određene kriterije vrednovanja razvijenosti i usvojenosti odgojnoobrazovnih ishoda [1].

U navedenim uvjetima promjene, u svijetu i u našoj zemlji stalno se grade nove škole i obnavljaju stare te i dalje postoji potreba za fizičkim prostorom u kojem će se učenici i studenti susretati s nastavnicima i edukatorima. Modificirani koncept škole, koja može postati i pristupna točka za virtualnu edukaciju ili za učenje koje spaja osobne s virtualnim interakcijama, zadržava svoju vrijednost i dugoročni potencijal.

\section{Učionica danas}

\subsection{Tradicionalna učionica}

Različita istraživanja su pokazala da je u zadnjih stotinjak i više godina osnovni raspored učionice ostao gotovo nepromijenjen bez obzira na 
pokušaje unaprjeđenja različitih struka - pedagoga, arhitekata, dizajnera školskog namještaja i drugih [2]. Učionice 19. stoljeća i prve polovice 20. stoljeća projektirane su s ciljem postizanja reda, discipline i školske higijene, čimbenika koji su smatrani preduvjetima dobrih edukacijskih praksi i pedagoških standarda (Slika 1). U njima nalazimo ploču, stolove i stolice za učenike, katedru za nastavnika, ormare za pohranu didaktičkih materijala i različite edukativne ilustracije po zidovima. Ploča služi kao žarište pažnje učenika i najvažniji je prostor transfera znanja u učionici.

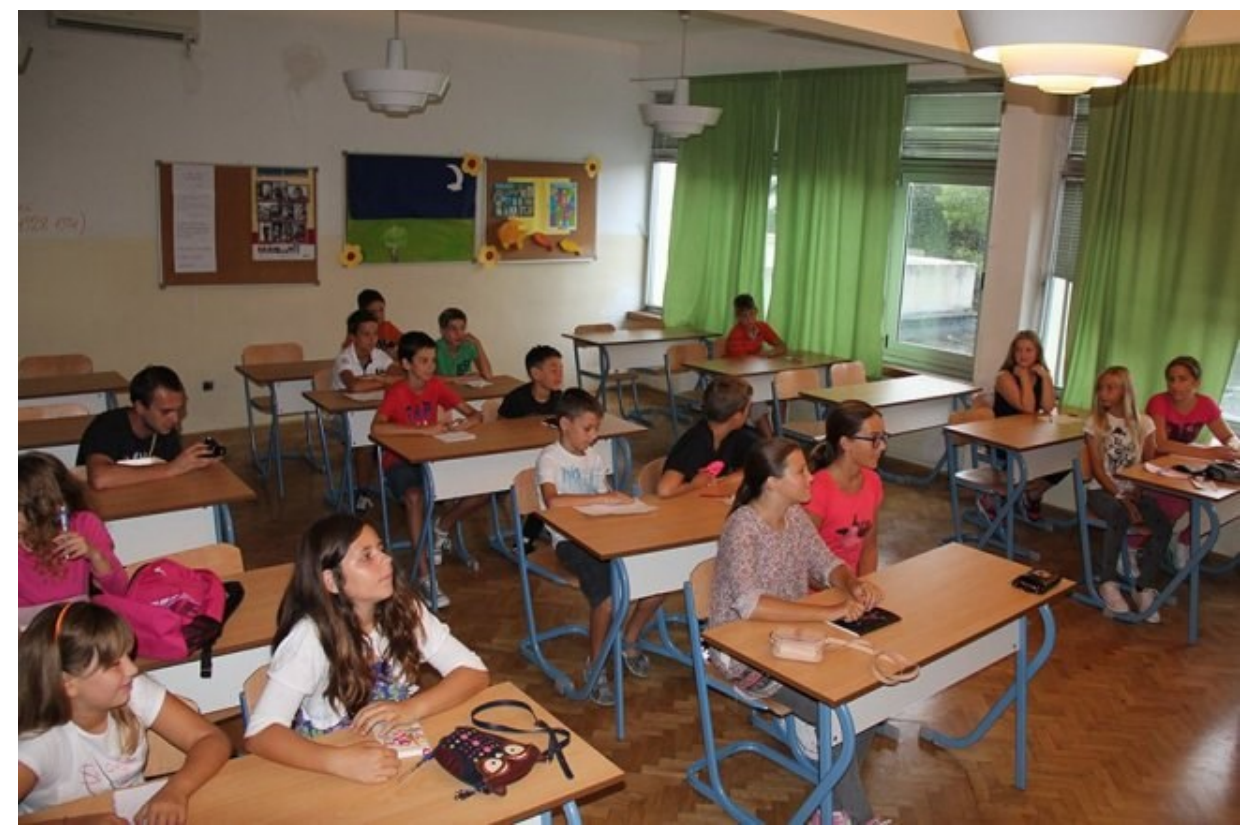

Slika 1. Tradicionalna učionica

\subsection{Elementi promjene}

\subsubsection{Novi koncepti učenja i podučavanja}

U izvještaju koji je 2015. godine publiciralo Međunarodno udruženje za tehnologiju u obrazovanju - ISTE naglašava se potreba za aktivnim prostorima učenja koji bi učenicima omogućili komunikaciju i kolaboraciju, slično kao što se od njih očekuje i na radnom mjestu. Aktivno učenje suprotstavlja se pasivnom učenju uključivanjem učenika u različite aktivnosti tijekom nastave kroz sintezu tehnologije, prostora i pedagogije. Ovakav koncept nije nov, ali, često su njegovu realizaciju sprječavala materijalna ograničenja učionice, pedagoških koncepata ili dostupnosti tehnologije. Istraživanje provedeno u visokom školstvu pokazuje da je u 
učionicama projektiranim s aktivnim učenjem u vidu postignut viši stupanj studentskog angažmana u području motivacije, inicijative, kreativnosti i postizanju više ocjene.

U drugoj polovici 20. stoljeća i početkom 21. stoljeća razvilo se više novih koncepata učenja i poučavanja. Ovdje će biti kratko opisano nekoliko najzastupljenijih inovativnih pedagoških pristupa - istraživačko učenje, obrnuta učionica, suradničko učenje, projektna nastava i igrifikacija.

Istraživačko učenje je pojam koji opisuje sudjelovanje učenika u istraživačkim aktivnostima $s$ ciljem poticanja interesa za znanost $i$ istraživanja, ali i s ciljem postizanja boljih komunikacijskih i prezentacijskih vještina učenika te sposobnosti grupnog rada [3].

Koncept „obrnute učionice“ podrazumijeva promjenu vremenskog rasporeda učenja tako da se učenik priprema za nastavu prije sata (učeći i istražujući izvan škole - kod kuće), a tijekom nastavnog sata, uz vodstvo učitelja, raspravlja o zadanim temama i sadržajima. Učenje kod ovakvog pristupa postaje fleksibilno (slobodan izbor vremena i mjesta učenja) i dijelom individualizirano [4].

Suradničko ili kooperativno učenje predstavlja rad učenika u grupama s ciljem zajedničkog učenja i rješavanja problema, a ishodi učenja uključuju razvijanje sposobnosti kritičkog mišljenja i zaključivanja te podizanje razine samopoštovanja i poštovanja drugih članova grupe [5].

Projektna nastava je pedagoški koncept u kojem učenici, uz moderiranje nastavnika, ishode učenja postižu istražujući stvaran problem iz vlastitog okruženja. Ovakav tip učenja je u pravilu interdisciplinaran, odvija se u fazama (od istraživanja do prezentacije) te je poticajan jer se rezultati mogu vidjeti i testirati na konkretnim zadatcima [6].

Igrifikacija (game-based learning) je tip učenja u kojem se „uči igrajući”, koristeći postojeće tipove poznatih ili edukativnih igara ili izmišljajući nove igre za odgovarajuće sadržaje. Učenje uz igru razvija koncentraciju, kognitivne i motoričke vještine, potiče kreativnost i problemski orijentirano razmišljanje te osigurava motivirajuće okruženje za učenje [4].

Uz navedene pristupe, u modernoj se pedagogiji često barata pojmovima scenarija - scenarija učenja i poučavanja. To su složeni pojmovi koji uključuju upotrebu i kombinaciju opisanih koncepata, uz aktivno sudjelovanje učenika te učestalu primjenu informacijsko komunikacijske tehnologije.

\subsubsection{Nove tehnologije}

U današnjim je školama sve jasnije da tradicionalna učionica, s učiteljem na čelu i učenicima koji su okrenuti prema učitelju, ne podržava opisane inovativne pedagoške procese. Prostori izgrađeni prije više desetljeća ili stoljeća ne odražavaju potrebe današnjih učenika, a pretpostavlja se da će 
novi ili modificirani prostori stimulirati i nove načine učenja i podučavanja [7].

Jedan od vidljivih elemenata promjene je sve veće prisustvo informacijsko komunikacijskih tehnologija u učionici. Informacijsko komunikacijska tehnologija je tehnologija koja koristi računala za prikupljanje, obradu, pohranu, zaštitu i prijenos informacija [8].

Trenutne spoznaje o informacijsko-komunikacijskoj tehnologiji koja bi se trebala nalaziti u modernoj učionici definiraju ovakav ili sličan sadržaj opreme:

- interaktivne bijele i pametne ploče

- video projektori ili interaktivni video projektori

- tableti

- računala (laptopi)

- digitalne i video kamere

- pisači i skeneri

- zvučnici

- slušalice

- mobilni namještaj (kolica, stolovi) za pohranu i punjenje mobilnih uređaja.

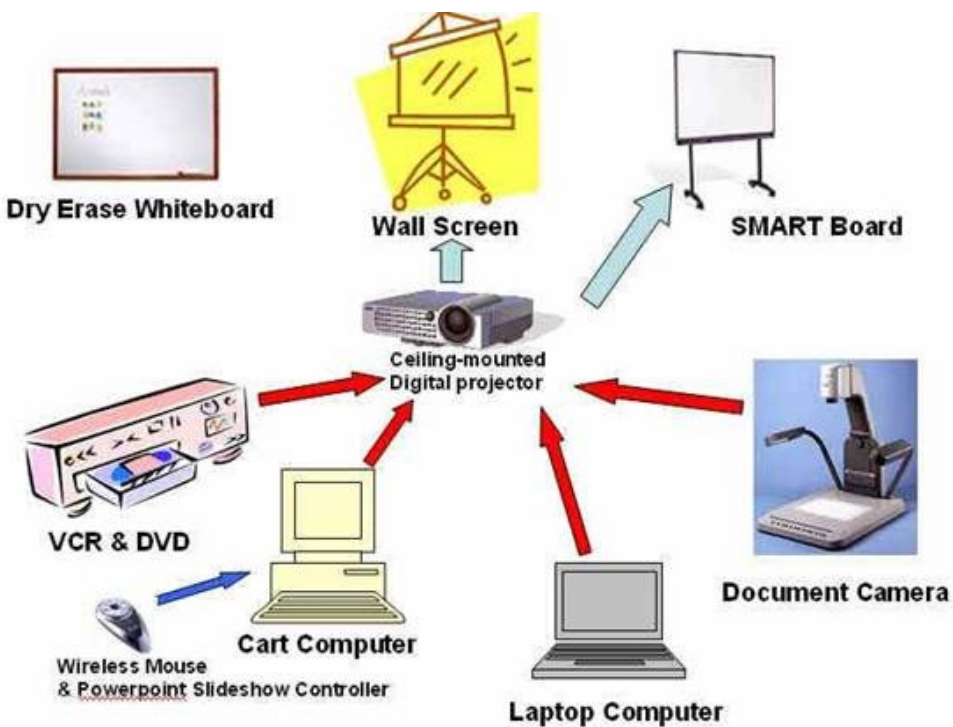

Slika 2. Informacijsko-komunikacijska oprema moderne učionice

Učenici i studenti sve više koriste i vlastite tehnologije na nastavi i izvan nje, a i učitelji prepoznaju tu potrebu za stalnim korištenjem tehnologije. Ipak, iako se danas može vrednovati rad i kreativnost učenika u području 
upotrebe novih tehnologija, njihov uspjeh i ocjene u velikoj mjeri ovise o tradicionalnom testiranju i rezultatima testova $i$ ispita.

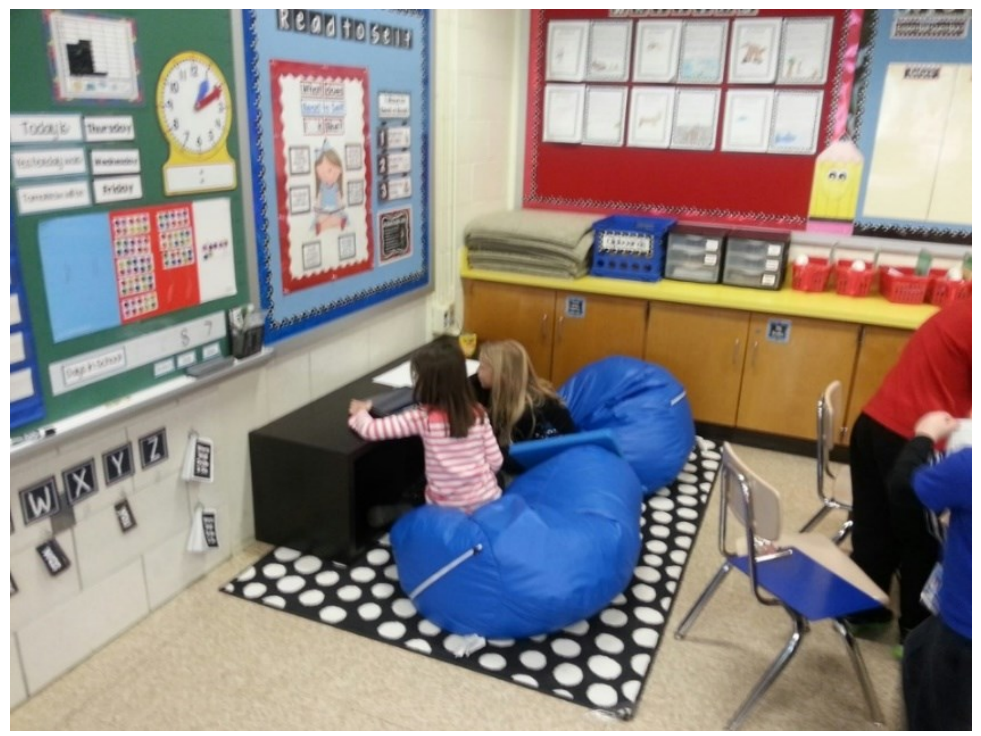

Slika 3. Personalizirano učenje u učionici 21. stoljeća

Potencijal novih tehnologija leži i u mogućnosti „personaliziranog“ učenja (Slika 3) te navodi na strukturiranje učionice u više različitih dijelova - zona - kako bi se pojedinci mogli simultano baviti različitim aktivnostima $\mathrm{u}$ istoj učionici. Također, tradicionalna ploča i katedra u ovom konceptu postaje samo jedna od fokalnih točaka učionice u kojoj je najvažnije vizualno žarište većinu vremena ekran ispred svakog učenika.

Neki autori tvrde da je položaj i kretanje učitelja u učionici najvažniji čimbenik projektiranja prostora učionice u doba kada u nju ulaze novi mediji učenja kao što su digitalni projektori, interaktivne bijele ploče, računala i mobilni uređaji. Kako su pojedini uređaji medijatori nastavnih sadržaja, njihov položaj oblikuje način podučavanja i učenja. Tako arhitektura učionice, namještaj i tehnologija koja se u njoj nalazi podržava određene aktivnosti i onemogućuje druge. Ipak, projektiranje učionice koja olakšava i potiče interakciju između učenja i okruženja u kojem se učenje odvija, uključivši materijalne i društvene aspekte uređenja, treba temeljiti na stvarnim [9], a ne pretpostavljenim, načinima upotrebe prostora (moguće nakon provedene analize upotrebe postojećih učionica).

Uz sve navedeno, istraživanja pokazuju da se u tehnološki naprednim obrazovnim prostorima, neovisno o drugim čimbenicima, ostvaruju bolji rezultati učenja. Nepromišljena promjena prostora neće samostalno dovesti do napretka u učenju i podučavanju - ona mora biti planirana i određena pedagoškim potrebama učenika 21. stoljeća. 


\subsubsection{Nova znanja potrebna radniku budućnosti}

Brojna su istraživanja provedena na temu znanja i vještina koje poslodavci danas traže od radnika koje zapošljavaju. U većini rezultata ove ili slične vještine nazivaju se ključnima za rad u 21. stoljeću (Slika 4):

- komunikacijske vještine

- sposobnost timskog rada

- kritičko razmišljanje

- inicijativa

- kreativnost

- digitalne kompetencije

- osobna i društvena odgovornost i

- sposobnost cjeloživotnog učenja.

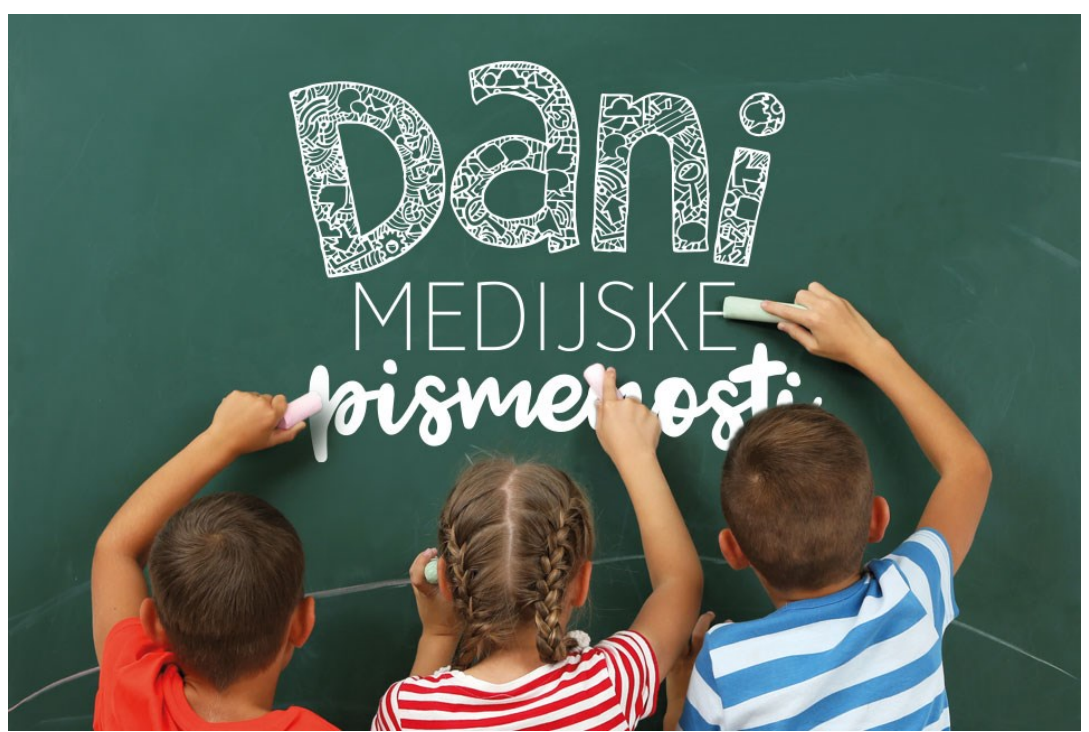

Slika 4. Komunikacijske vještine ključne za radnika 21. stoljeća

Pitanje je kako učenike naučiti ove vještine, kojim ih procesima provjeravati i u kakvom prostoru ih najlakše ostvariti.

\section{Učionica budućnosti}

Organizacija za ekonomsku suradnju i razvoj - OECD, definira „obrazovni prostor" kao materijalni prostor koji podržava višestruke i raznolike programe učenja i podučavanja, uključivši moderne tehnologije, koji osigurava optimalnu i financijski učinkovitu izvedbu i održavanje tog prostora kroz vrijeme, koji je u suglasju s okolišem, koji ohrabruje 
društvenu interakciju i stvara zdravo, ugodno, sigurno i stimulativno okruženje za svoje korisnike. Taj prostor je, u najužem smislu, učionica, a u najširem smislu kombinacija formalnog i neformalnog obrazovanja u kojem se učenje odvija kako unutar tako i izvan škole.

Učionica budućnosti može se definirati kao materijalno okruženje koje integrira najnaprednije pedagoške koncepte i edukacijske tehnologije $s$ ciljem postizanja kvalitetnijih ishoda učenja.

Učionica budućnosti trebala bi sadržavati minimalno tri glavna područja (zone) za učenike; jedno je područje grupiranih i umreženih računala, drugo je područje $s$ učeničkim klupama, interaktivnom pločom i monitorom povezanim $s$ učiteljevim računalom, a treće je područje grupnog rada. Različiti autori zagovaraju od četiri do sedam i više ovakvih segmentiranih zona unutar učionice [10].

U projektu Future Classroom Lab [9] definirano je šest zona učenja istraživanje, kreacija, prezentacija, interakcija, razmjena, razvoj - i svaka je fokusirana na različite pristupe ili vidove učenja i podučavanja (Slika 5). Zoniranje omogućava vizualizaciju pedagoških scenarija u učionici i potiče „dobro učenje” opisano izjavama biti povezan, uključen i potaknut.

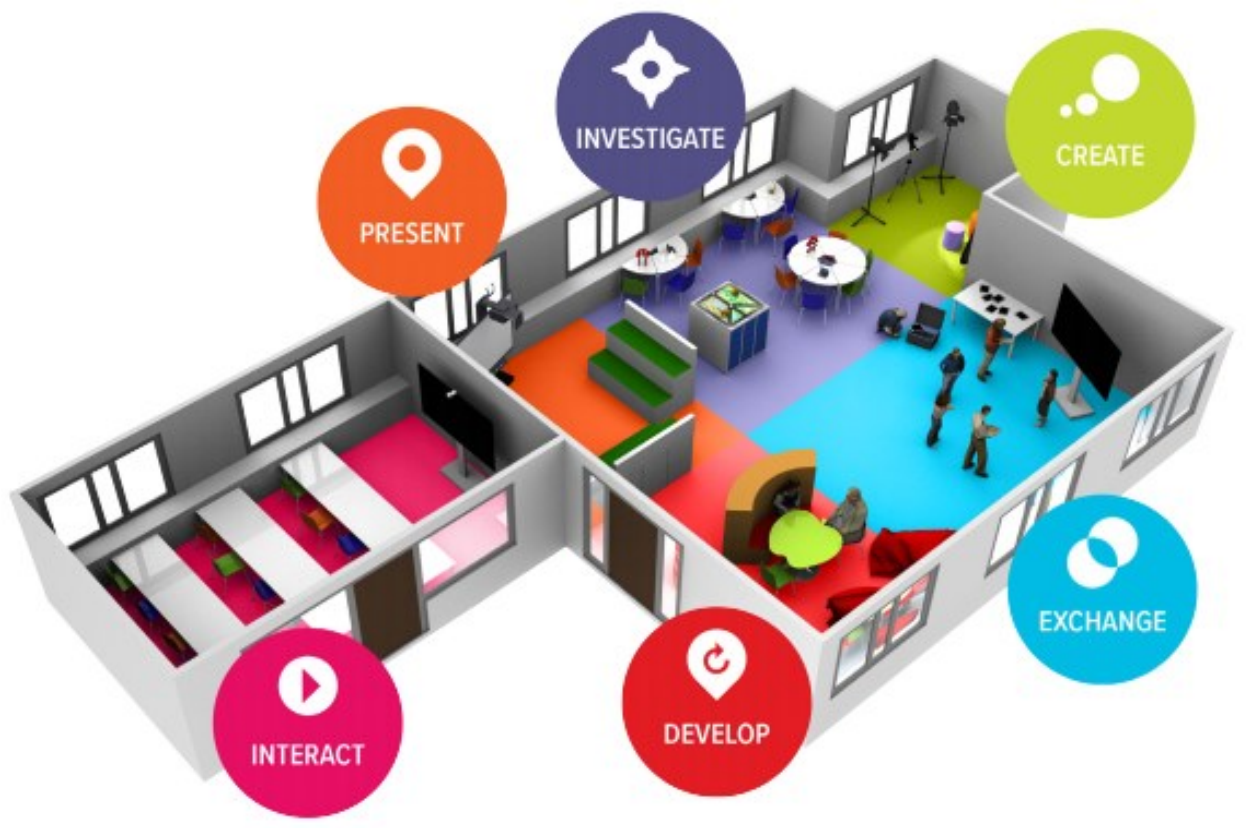

Slika 5. Šest zona učionice po Future Classroom Lab

Osnovne materijalne značajke učionice 21. stoljeća su [11]:

- visoka razina opremljenosti informacijsko komunikacijskom tehnologijom 
- višesmjerno funkcioniranje učionice - centralno pozicionirane ploče ili ploče na obje strane učionice, mobilna kolica-ormarići pomoću kojih se po potrebi mijenja položaj opreme

- zajednička upotreba resursa - više razreda dijeli zajedničke zone opremljene za određenu namjenu kao što je zona za umjetničke projekte (tu postoji dovod tekuće vode i odvodnja), zona za multimedijalne projekte (zvučna soba, oprema za snimanje i projekcije) i

- mobilijar učionice - stolice, stolove, ormare moguće je jednostavno premještati i reorganizirati.

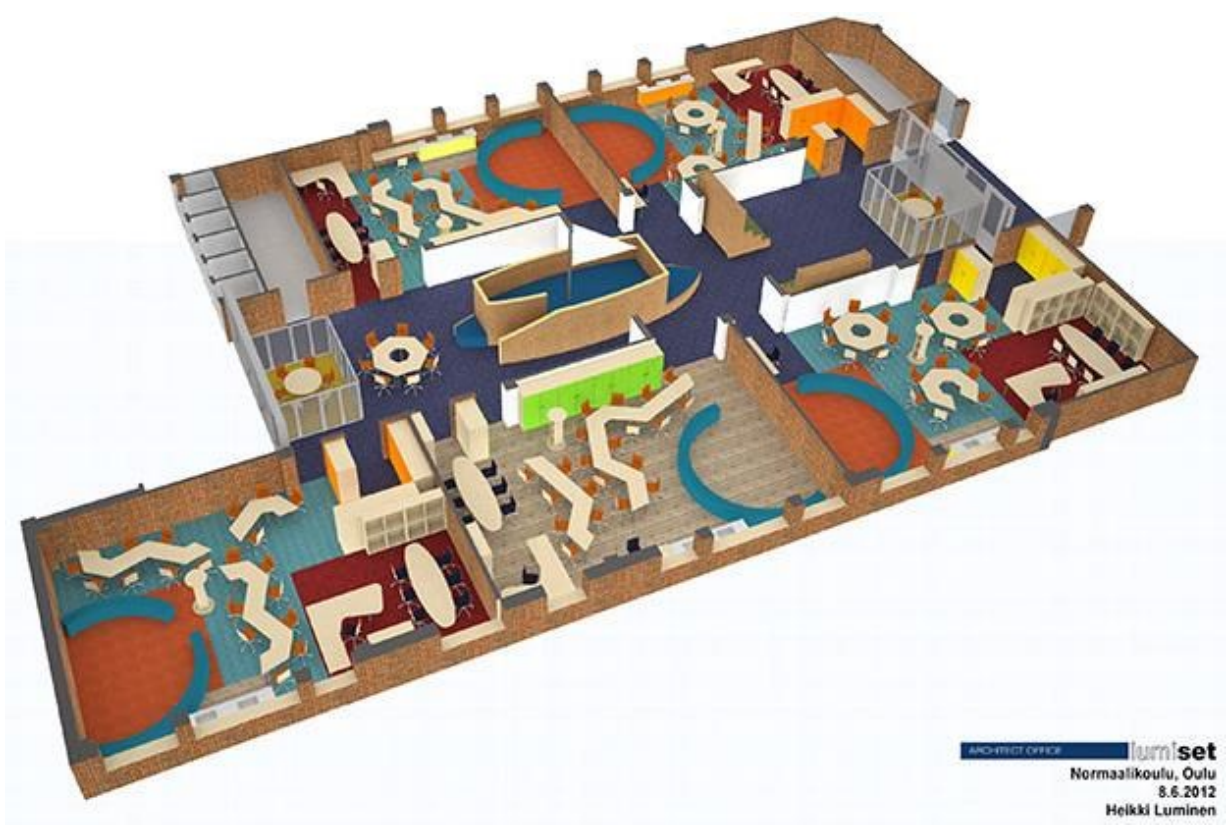

Slika 6. Organizacija prizemlja UBIKO škole, Finska

Neki radikalniji projekti „ruše“ zidove učionica i definiraju ih pomoću namještaja (ormara, tepiha, stolica) kao funkcionalne, meko ograničene cjeline (primjer UBIKO škole na Sveučilištu Oulu u Finskoj) [2]. Učenici na nastavu donose vlastite laptope ili tablete i povezuju se bežičnom vezom $u$ svim dijelovima prostora (Slika 6). 


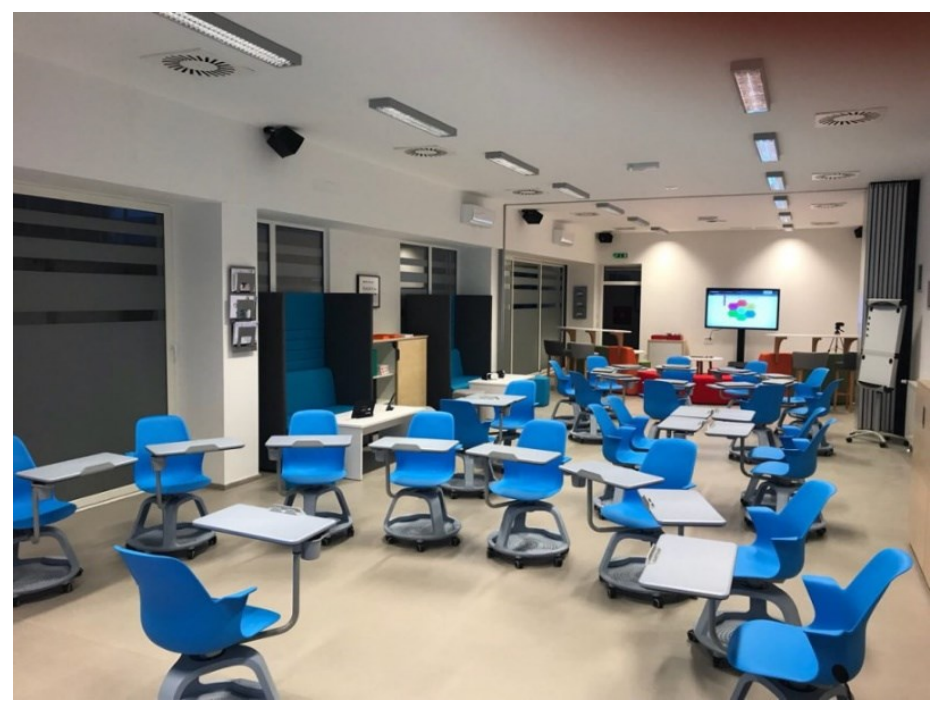

Slika 7. Učionica budućnosti, Srednja škola Ivanec

U Srednjoj školi Ivanec je u ožujku 2018. otvorena „učionica budućnosti" kao jedna od 12 takvih učionica u Europi (Slika 7). Učionica je umrežena bežičnim internetom i posjeduje 25 laptopa, bežični 3D printer, skener i kopirni aparat, veliki interaktivni zaslon, virtualne naočale, setove za robotiku, kameru i fotoaparat. Po prije opisanom konceptu Future Classroom Lab, učionica je podijeljena u šest zona učenja namijenjenih razvijanju različitih načina učenja uz naglasak na interakciji, razvoju, kreiranju, istraživanju, prezentaciji i suradnji [12] .

Napomena: prema podatcima iz lokalnog tiska, ukupna vrijednost investicije „učionice budućnosti“ je 970.000 kuna. Od toga je 640.000 kuna utrošeno u građevinske radove, a 330.000 kuna u opremu. Ministarstvo regionalnog razvoja i fondova EU odobrilo je, nakon prijave na natječaj, Srednjoj školi Ivanec svotu od 144.000 kuna, škola je izdvojila vlastita sredstva u iznosu od 110.000 kuna, a većinu sredstava, oko 720.000 kuna, osigurala je Varaždinska županija [12] .

\section{Ilustracije učioničkih prostora u dvije škole}

\subsection{Le Chéile Secondary school, Irska}

Škola Le Chéile u Irskoj započela je radom u novoj zgradi 2016. godine. Svaka učionica opremljena je setom namještaja od 15 dvostrukih klupa, 30 stolica u različitim bojama, jednim stolom i stolicom za učitelja, jednim mobilnim kolicima za malu učioničku opremu, projektorom i dvije standardne ploče, a iPad je osiguran za svakog učenika i učitelja [9]. 


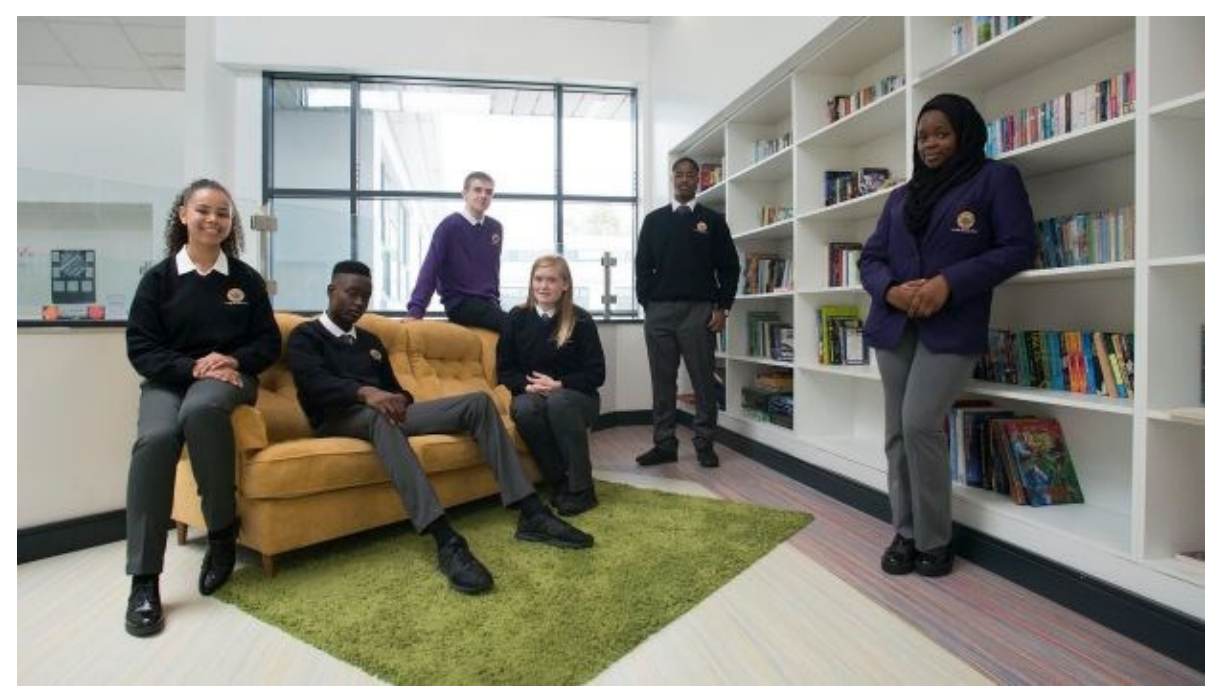

Slika 8. Prostori za učenje, škola Le Chéile, Irska

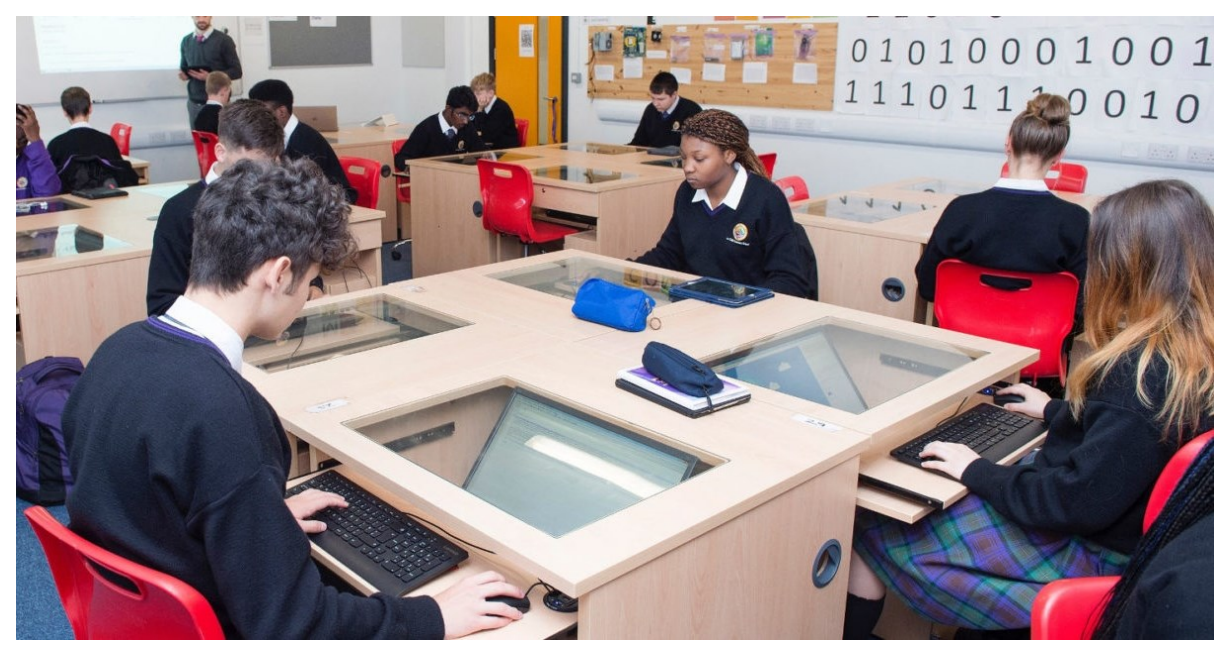

Slika 9. Prostori za učenje, škola Le Chéile, Irska 


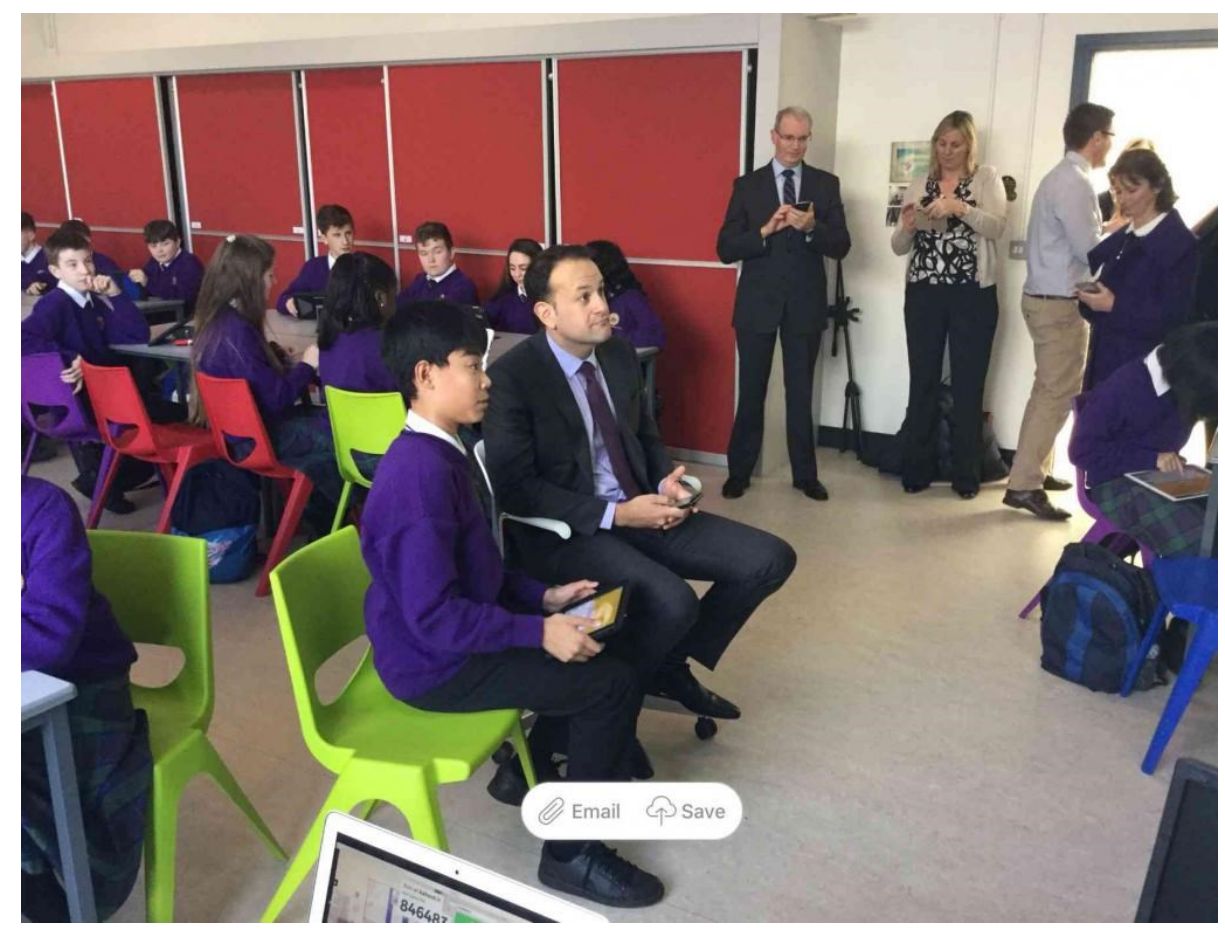

Slika 10. Prostori za učenje, škola Le Chéile, Irska

\subsection{Istituto Comprensivo di Cadeo e Pontenure, Roveleto, Italija}

U školi Istituto Comprensivo di Cadeo e Pontenure postoje različite prostorije s pokretnim namještajem i područja s udobnim jastucima za učenike, s integriranom tehnologijom koja uključuje pametne ploče, laptope i tablete za svakog učenika i učitelja [4]. Posebna pažnja posvećena je podučavanju umjetničkih predmeta; u školi se nalaze dva glazbena laboratorija s instrumentima u kojima se održavaju koncerti koji se „dijele“ na internetu (važan dio vizije ove škole je sudjelovanje u životu zajednice). 


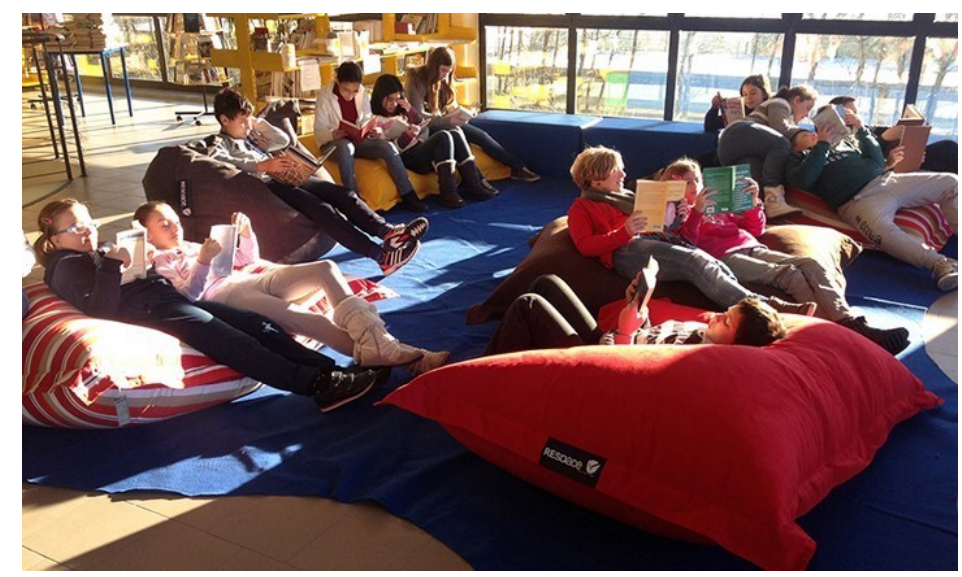

Slika 11. Prostori za učenje, Istituto Comprensivo di Cadeo e Pontenure

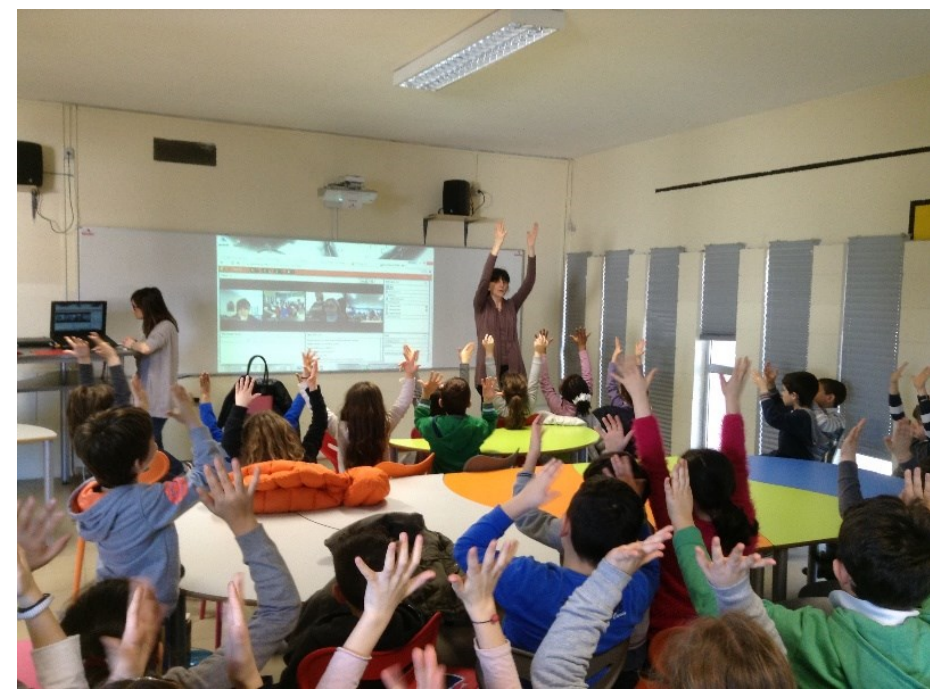

Slika 12. Prostori za učenje, Istituto Comprensivo di Cadeo e Pontenure 


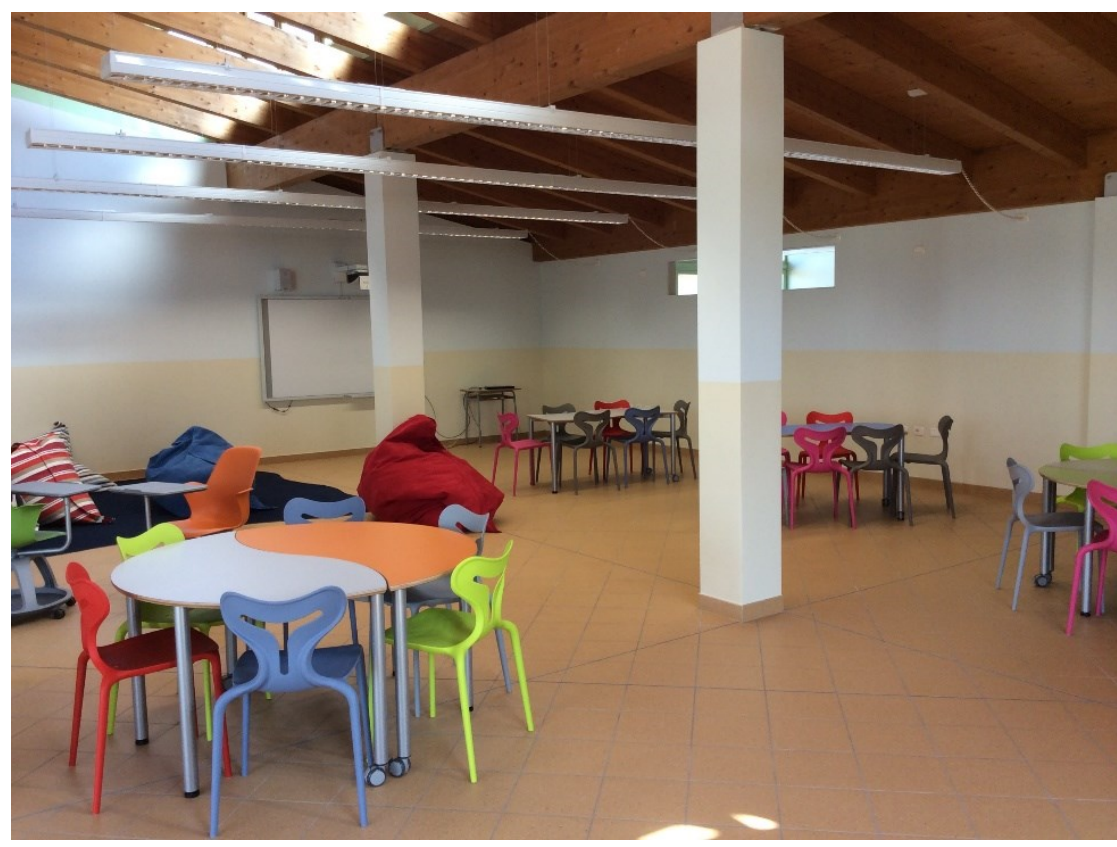

Slika 13. Prostori za učenje, Istituto Comprensivo di Cadeo e Pontenure

\section{Zaključak}

Iz istraživanja prikazanih u tekstu vidljivo je da je krajem 20. i početkom 21. stoljeća došlo do radikalnih promjena u izgledu i načinu funkcioniranja tradicionalne učionice (13).

Dva su osnovna čimbenika koja su dovela do promjene koncepta učionice. Jedan čimbenik je razvoj pedagoške teorije i prakse unutar kojeg inovativni pristupi poput suradničkog, projektnog i problemskog učenja, „okrenute učionice“ ili igrifikacije naglašavaju potrebu za drugačijom organizacijom prostora za učenje. Drugi čimbenik promjene je pojava i sve veća zastupljenost informacijsko-komunikacijskih tehnologija, kako u svakodnevnom životu, tako i u školi.

„Učionica budućnosti” naziv je za učionicu 21. stoljeća, a označava funkcionalan, fleksibilan i komponibilan prostor za učenje i podučavanje, opremljen najmodernijom informacijsko-komunikacijskom tehnologijom.

Takva učionica podijeljena je na zone, najčešće od tri do šest zona, koje omogućavaju sukcesivno ili simultano odvijanje različitih tipova učenja i podučavanja. Segmentiranost učionice je element fleksibilnosti jer se u njoj može naći mjesto za raznovrsne aktivnosti učitelja i učenika u okviru nastave kao i poticaj za individualno učenje.

Sve pedagoške procese u učionici podržavaju informacijsko komunikacijski alati kao što su interaktivne ploče, projektori, računala i 
tableti, kamere, pisači, skeneri i zvučnici. Učitelji i učenici pomoću tehnologije mogu birati kada, gdje i s kim učiti i kako spojiti kontaktno i virtualno učenje. Istraživanja provedena u okviru ovog rada pokazuju da prostor može biti „partner“ pedagogiji, ali i barijera koja sprječava realizaciju nekih vidova suvremenog učenja i podučavanja [2]. Zato pozicioniranje informacijsko komunikacijske tehnologije u učionici ne treba odgovarati samo pojedinom pedagoškom pristupu, već treba omogućiti odvijanje više tipova učenja i podučavanja i njihovu potencijalnu integraciju.

Uz elemente uređenja učionice kao što su namještaj, tehnologija, položaj zona učenja, potrebno je učionicu tretirati kao dio škole i zajednice koja je okružuje. Stoga treba razmišljati i o korištenju ovih prostora izvan i poslije školskog dana, o poziciji djece s posebnim potrebama u ovim (prostornim) sustavima, o prostoru za suradnju s gospodarskim subjektima, o mjestu za prezentaciju umjetničkog obrazovanja. Izgradnja novih škola i učionica mora biti i financijski učinkovita jer je veliki trošak njihove gradnje i opremanja značajan ograničavajući faktor u povećanju broja modernih prostora za učenje.

Kreiranje kvalitetnih učioničkih i školskih prostora složen je zadatak i temelji se na suradnji pedagoga i arhitekata, sociologa, dizajnera opreme i namještaja, učitelja, roditelja, lokalne i šire zajednice. Kada takva suradnja rezultira svijetlim, šarenim, poticajnim i aktivnim prostorima, onda i odrasli, kao u primjeru roditelja učenika irske škole Le Chéile, požele ponovno krenuti u školu.

\section{Literatura}

[1] https://mzo.hr/sites/default/files/dokumenti/2018/OBRAZOVANJE/Nacion alni-kurikulumi/Skola-za-zivot/eksperimentalni program-skola za zivot.pdf (9.12.2018.)

[2] J. Tondeur, E. De Bruyne, M. Van Den Driessche, S. McKenney \& D. Zandvliet (2015) The Physical Placement of Classroom Technology and Its Influences on Educational Practices, Cambridge Journal of Education, 45:4, 537-556, DOI: 10.1080/0305764X.2014.998624.

[3] Ristić Dedić, Z. (2013) Istraživačko učenje kao sredstvo i cilj prirodoznanstvenog obrazovanja: psihologijska perspektiva, Dijete, vrtić, obitelj, broj 73, str. 4-7

[4] Primjena scenarija poučavanja, digitalnih alata i obrazovnih trendova priručnik (2017), Hrvatska akademska i istraživačka mreža - CARNet, Zagreb.

[5] Peko, A. i dr. (2006) Suradničko učenje u mlađoj školskoj dobi, Život i škola, broj 15-16, str. 17-28

[6] Dolaček, Z., Lončar-Vicković, S., Stober, D. (2011) Projektna nastava u obrazovanju građevinskih inženjera, Građevinski fakultet Osijek 
[7] Oblinger D. (2005) Leading the Transition from Classrooms to Learning Spaces, Educause Quarterly Volume 28, Number 1, 2005 ISSN 1528-5324, pp. 14-18

[8] Smiljčić, I., Livaja, I., Acalin, J. (2017), ICT u obrazovanju, Zbornik radova Veleučilišta u Šibeniku, broj 3-4, str. 157-170

[9] Guidelines on Exploring and Adapting LEARNING SPACES IN SCHOOLS (2017) European Schoolnet (EUN Partnership AISBL), http://www.indire.it/wpcontent/uploads/2018/04/Learning spaces guidelines ENG.pdf (15.8.2018.)

[10] Olsson, L., Koroma, E. (2008), A FUTURE LEARNING SPACE: THE CLASSROOM? Eden Annual Conference, Lisabon https://www.edu.su.se/polopoly fs/1.87639.1336567017!/menu/standard/ file/Olsson Koroma.pdf (15.8.2018.)

[11] Eadie, G. M. (2001) The Impact of ICT on Schools: Classroom Design and Curriculum Delivery A Study of Schools in Australia, USA, England and Hong Kong

[12] http://www.varazdinske-vijesti.hr/obrazovanje/foto-u-srednjoj-skoliivanec-otvorena-ucionica-buducnosti-22944/ (20.9.2018.)

[13] http://blogs.worldbank.org/edutech/re-thinking-school-architecture-in-theage-of-ict (20.08.2018.)

\section{Izvori ilustracija}

Slika 1 https://dubrovackidnevnik.rtl.hr/vijesti/grad/pocela-je

Slika 2 https://blog.econocom.com/en/blog/how-to-successfully-deploy-adigital-classroom/

Slika 3 https://www.medijskapismenost.hr/dani-medijske-pismenosti/

Slika 4 http://lighthouse.bcps.org/reflections/secondary-stat-teachers-visitlighthouse-schools

Slika 5 http://www.eun.org/professional-development/future-classroom-lab

Slika 6 http://www.ubiko.eu/background.html

Slika 7 http://www.varazdinske-vijesti.hr/obrazovanje/foto-u-srednjoj-skoliivanec-otvorena-ucionica-buducnosti-22944/

Slika 8 https://www.irishtimes.com/news/education/with-67-nationalities-is-

this-ireland-s-most-diverse-school-1.3603249

Slika 9 http://lecheilesecondaryschool.ie/about/welcome/

Slika 10 https://www.uniqueschoolapp.ie/site/photos/school id/75/album id/

1250/album title/Leo\%20Varadkar\%20visit

Slika 11 http://www.istitutocomprensivocadeo.it/progetti/progetti-

ttecnologici/etwinning/

Slika 12 http://www.istitutocomprensivocadeo.it/progetti/progetti-

ttecnologici/etwinning/

Slika 13 http://www.istitutocomprensivocadeo.it/progetti/progetti-

ttecnologici/etwinning/ 